\title{
PROSPECTS FOR IMPROVEMENT THE SOCIAL SERVICES ORGANIZATION IN UKRAINE IN THE CONDITIONS OF THE SOCIAL MANAGER POSITION IMPLEMENTATION
}

\author{
Marta Kozak ${ }^{1}$, Olena Zaichenko ${ }^{2}$ (Lviv) \\ Lviv Polytechnic National University, Lviv, Ukraine \\ ${ }^{1}$ Ph.D., Associate Professor, of Department of Sociology and Social Work \\ ${ }^{2}$ Student of master program "Social Work", of Department of Sociology and Social Work
}

Background: Modern processes of transformation of the social service delivery system in Ukraine are directly linked to the implementation of new and effective management methods and models that meet international standards, consolidate and promote European values. However, social work rarely becomes the object of scientific research in terms of management aspects of its implementation. The implementation of a number of new regulations in the field of social protection of the population in Ukraine, which establish the state standards for social services, determine the place and role of social work subjects in the context of decentralized processes of public administration, also require detailed study, analysis and systematization. A multi-purpose social system requires that the management mechanism ensures a clear interaction of all its subsystems and helps maximize efficiency in the tasks it has set. Thus, the study of the relatively new category of social and managerial legal category of "social manager" deserves special attention, as well as the analysis of the possibilities of improving the provision of social services in the conditions of implementation of such a position.

Purpose: analysis of the role and authority of the social manager in the context of changes in the organizational structure of social services management and the possible impact of such reorganization on the quality of social services.

Methods: theoretical methods of scientific research, such as analysis of legal acts, scientific literature on the topic of research, synthesis of information obtained and generalization on the basis of the obtained data, were used in the work to clarify changes in the organization of social services in the implementation of the position of social manager.

Results: Social management - a type of management, which involves the formation of strategic goals and the development of plans for their implementation, taking into account the identified problems, factors of external and internal environment of the social organization, using the functions and methods of management within a certain process (technology) in the social sphere. The social manager is given the role of establishing public relations, partnerships, finding and attracting resources for the implementation of social projects. A social manager would act as an intermediary between social service providers and recipients, an effective decision-making center, based on a holistic and systematic analysis of the community's needs on the one hand, the opportunities and challenges faced by its team of workers, on the other.

Conclusion: Therefore, social management is the process of managing the development, formation and effective use of social systems at different levels of government. Focusing on improving the overall well-being of the population, the need for timely identification and overcoming of social problems requires the separation of management in social management, which would have the authority of operational administration, such as a social manager. The main results of the introduction of the position of social manager may be to optimize the functioning of the social service, to obtain a more significant effect at the least effort, cost and time. In our view, the introduction of this position in social activities will also imply improved service delivery.

Keywords: social work, social management, social manager, social services.

Сучасні процеси трансформації системи надання соціальних послуг в Україні безпосередньо пов'язані 3 впровадженням нових та ефективних методів та моделей управління, що відповідали б міжнародним стандартам, закріплювали та утверджували би європейські цінності. Однак соціальна робота рідко стає об'єктом наукових досліджень 3 
точки зору управлінських аспектів іiі реалізації. Впровадження низки нових нормативноправових актів в галузі соціального захисту населення в Україні, що закріплюють державні стандарти надання соціальних послуг, визначають місце і роль суб'єктів соціальної роботи в умовах децентралізаційних процесів державного управління, також вимагають детального вивчення, аналізу та систематизації. Багатоцільова соціальна система вимагає, щоб механізм управління забезпечував чітку взаємодію всіх його підсистем і сприяв максимізації ефективності у виконанні поставлених перед ним завдань. Таким чином заслуговує на особливу увагу дослідження відносно нової для соціальної роботи в Україні управлінськоправової категорії «соціального менеджера», а також аналіз можливостей вдосконалення надання соціальних послуг в умовах впровадження такої посади.

Мета: аналіз ролі та повноважень соціального менеджера в умовах змін організаційної структури управління соціальними службами та можливий вплив такої реорганізації на якість надання соціальних послуг.

Соціальний менеджмент - різновид менеджменту, котрий передбачає формування стратегічних цілей та розробку планів до їх реалізації, з врахуванням виявлених проблем, факторів зовнішнього та внутрішнього середовища соціальної організації, використовуючи функції та методи управління в рамках певного процесу (технології) в соціальній сфері. Особливістю соціального управління є некомерційне підгрунтя діяльності в цій сфері, адже вирішення соціальних проблем, надання соціальних послуг та задоволення потреб клієнтів не супроводжується отриманням безпосередньо прибутку. Тому оцінити ефективність менеджменту в напрямі можна лише 3 позиції підвищення соціального благополуччя населення та позитивних змін в суспільстві (Попов С. Г., 2009, с.13).

До об’єктів соціального менеджменту можна віднести соціальні явища, стосунки людей в соціальній сфері. Предметом соціального менеджменту визначається як соціальна діяльність, що здійснюється в різних сферах і на різних рівнях соціальної системи (Коленда, Н. 2016, с. 32).

Досліджено, що соціальна робота реалізується через посередництво історично сформованих типів і форм взаємодії і стосунків людини з іншими людьми. Вона може знайти своє втілення в різних сферах і на різних рівнях соціальної організації суспільства. Соціальні процеси достатньо різноманітні. Вони пов'язані з соціальними стосунками між індивідами і соціальними групами як носіями різних видів діяльності та розрізняються соціальними позиціями і ролями в житті суспільства, тобто пов'язані з певними видами відношень даного суспільства.

Варто також відзначити функції управління в соціальній роботі. Планування соціального менеджменту полягає у використанні системи показників діяльності, необхідної для подальшого контролю результатів, забезпеченню взаємозв'язку цільових показників діяльності та виявлених соціальних потреб і проблем населення, що дозволяє чітко визначати цілі та плани діяльності соціальної служби. Функція організування визначає виконання соціальним менеджментом комплексу дій, формулюванням рішень та залученням необхідних ресурсів для виконання певного управлінського рішення. Мотивування в соціальному менеджменті слід розуміти, на нашу думку, як сукупність факторів, механізмів і процесів, які спонукають до досягнення необхідних цілей соціальної організації. Функція координування допомагає досягненню узгодженості в роботі всіх ланок організації, забезпечення єдності і узгодженості всіх стадій процесу соціальної діяльності. Комунікація в соціальній роботі належить до фундаментальних аспектів та інструментів якісного надання соціальних послуг, адже забезпечує розширення інформаційної бази організації, сприяє обміну інформацією між клієнтом та працівником соціальної служби для досягнення поставленої цілі. Реалізація функції контролювання діяльності організації дає змогу належним чином оцінити проведену соціальну роботу та визначити напрями підвищення їі ефективності (Попов С. Г., 2009, с. 27), (Осипенко, Л. О., 2013, с. 247).

Визначено, що організаційні структури соціального менеджменту можуть створюватися в формі державного/комунального та недержавного сектору. Важливе завдання менеджменту забезпечити узгодження всіх компонентів структури організації. Оскільки організація як соціальна система представляє собою сукупність соціальних груп, статусів і т. д., то 
впорядкованість, ієрархія складає важливу властивість. В загальному вигляді охарактеризувати рівні управління в соціальному менеджменті можна за допомогою схеми (рис.1):

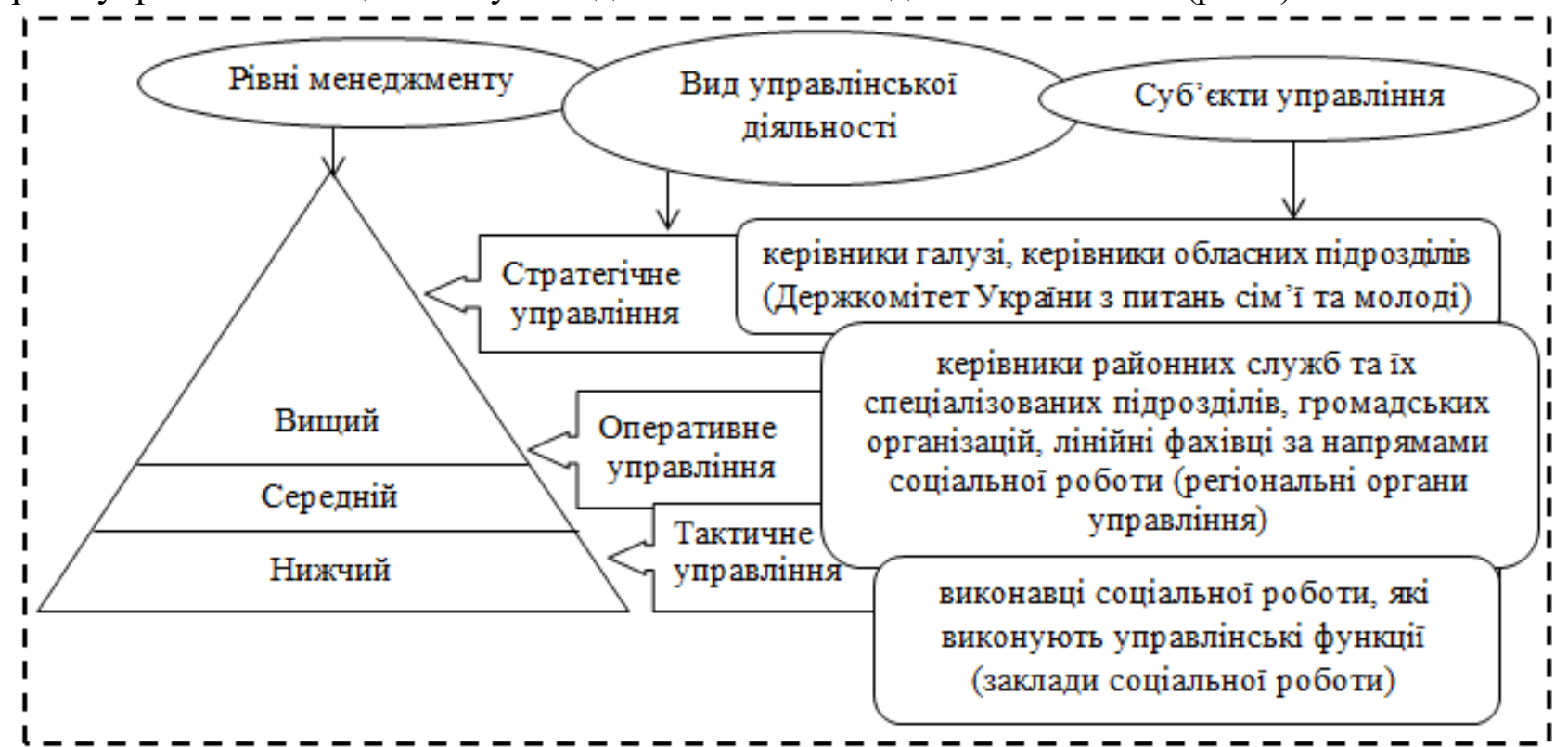

Рис 1. Характеристика рівнів менеджменту соиіальної роботи в Украӥні *розроблено автором

Відповідно до прийнятого ЗУ «Про соціальні послуги» в структурі управління соціальною роботою в Україні виокремлюється така ланка, як «соціальний менеджер», що має такі повноваження:

- планування, організація, координація, моніторинг здійснення соціальної роботи, надання соціальних послуг у територіальній громаді;

- залучення ресурсів територіальної громади для здійснення соціальної роботи та надання соціальних послуг;

- звітування місцевому органу виконавчої влади, органу місцевого самоврядування про здійснення соціальної роботи та надання соціальних послуг у територіальній громаді;

- підготовка та подання до місцевого органу виконавчої влади, органу місцевого самоврядування пропозицій щодо удосконалення місцевих програм, що передбачають здійснення соціальної роботи та надання соціальних послуг;

- проведення інформаційно-роз'яснювальної роботи щодо соціальної роботи та надання соціальних послуг;

- здійснення оцінювання потреб у соціальних послугах сімей, дітей та молоді;

- здійснення інших повноважень щодо соціальної роботи та надання соціальних послуг відповідно до закону (Закон України «Про соціальні послуги», 2019).

Варто наголосити на ключових, на наш погляд, особливостях в повноваженнях соціального менеджера, що відрізнятимуть його від інших надавачів соціальних послуг, такх як фахівець соціальної роботи, соціальний працівник. Соціальному менеджеру відводиться роль налагодження зв'язків з громадськістю, партнерства, пошуку та залучення ресурсів для реалізації соціальних проектів. Реалізація соціальної політики в територіальній громаді теж належатиме до компетенції соціального менеджера. Іншим, не менш важливим, аспектом його діяльності мало б стати гнучке оперативне планування та координування соціальної роботи безпосередньо «на місцях», прийняття необхідних та вчасних управлінських рішень що допомогли б виявити потреби клієнтів в соціальних послугах та в максимально можливій мірі допомогти у вирішенні соціальних проблем.

Проаналізувавши схему (рис. 1) та ЗУ «Про соціальні послуги», можна зазначити, що в Україні соціальний менеджер займає нижчу ланку менеджменту. Аналіз зарубіжного досвіду соціальної роботи, натомість, показує, що соціальні менеджери найчастіше належать до середнього рівень управління. Таким чином можна зробити висновок, що управлінська роль, 
яка відводиться соціальному менеджеру не є однаковою в різних державах (Надвинична, Т., 2011, c.118).

Незважаючи на те, що поняття «соціального менеджера» закріплено в чинному законодавстві нашої держави, слід наголосити на тому, що сутність, роль, місце соціального менеджера в діяльності соціальних служб можна потрактувати неоднозначно. На нашу думку, введення посади «соціального менеджера» в функціонування центрів надання соціальних послуг i термінологію вітчизняного законодавства може бути обгрунтованим в різний спосіб. Зокрема, причиною може бути запровадження ведення випадку (кейс-менеджменту) як нового способу роботи з клієнтом, що, відповідно, вимагає наявності суб'єктів такої діяльності - менеджерів.

Іншою причиною, на наш погляд, можна вважати доцільність розмежування управлінських та виконавчих функцій, які були до цього часу притаманні фахівцю соціальної роботи. Це допомогло б зменшити навантаження на соціальних працівників, що в свою чергу могло вплинути на ефективність надання соціальних послуг.

Третьою, не менш суттєвою причиною, може слугувати зростання попиту на адміністративний персонал нижчої ланки управління у зв'язку з процесами децентралізації : перенесення центрів прийняття управлінських рішень 3 регіональних структур на місцеві, локальні (ОТГ) вимагає закріплення за працівниками соціальних служб управлінських повноважень.

Можемо спрогнозувати, що соціальний менеджер зайняв би місце посередника між надавачами та отримувачами соціальних послуг, ефективного центру прийняття рішень, на основі цілісного та систематизованого аналізу потреби громади з одного боку, можливостей і викликів, які постають перед його командою працівників, - 3 іншого.

Отже, соціальний менеджмент - це процес управління розвитком, формуванням та ефективним використанням соціальних систем на різних рівнях управління.

Орієнтація на підвищення загального добробуту населення, необхідність у вчасному виявленні та подоланні соціальних проблем вимагає виокремленні управлінської ланки в соціальному менеджменті, що володіла б повноваженнями оперативного адміністрування, такого як соціальний менеджер.

Головними результатами впровадження посади соціального менеджера, можливо будуть оптимізація функціонування соціальної служби, отримання більш суттєвого ефекту при найменших зусиллях, витратах, а також і витратах часу. На нашу думку, впровадження цієї посади в соціальній діяльності передбачатиме також покращення надання послуг.

\section{References}

The Verkhovna Rada of Ukraine (2019). Law of Ukraine "On Social Services" https://zakon.rada.gov.ua/laws/show/2671-19

Kolenda, N. (2016). Theoretical approaches to defining the essence of the concept of "social management". Economic Journal of the Eastern European National University. Lesya Ukrainka, 3, 32-36. Retrieved from URL: http://nbuv.gov.ua/UJRN/echcenu_2016_3_7

Nadvynichna, T. (2011). Social management: the perspective of technology. Psychology and Society, 1, 114-121. Retrieved from URL: http://psl.onu.edu.ua/index.

Osipenko, L. O. (2013). The communicative process as a whole sociocultural system: a sociophilosophical analysis. Humanities Bulletin, 54, 241-250. Retrieved from URL: http://nbuv.gov.ua/UJRN/znpgvzdia_2013_54_23.

Popov S. G. (2009). Social management. Axis-89, 10-61. Retrieved from URL: https://obuchalka.org/2012112268215/social-management-popov-s-g-2009.html

\section{Список використаних джерел}

Верховна Рада України (2019). Закон України «Про соціальні послуги» https://zakon.rada.gov.ua/laws/show/2671-19

Коленда, Н. (2016). Теоретичні підходи до визначення сутності поняття «соціальний менеджмент». Економічний часопис Східноєвропейського національного університету 
ім. Лесі Українки, 3, 32-36. Retrieved from URL: http://nbuv.gov.ua/UJRN/echcenu_2016_3_7

Надвинична, Т. (2011). Соціальний менеджмент: перспектива технологізації. Психологія $i$ суспільство, 1, 114-121. Retrieved from URL: http://psl.onu.edu.ua/index.

Осипенко, Л. О. (2013). Комунікативний процес як цілісна соціокультурна система: соціально-філософський аналіз. Гуманітарний вісник, 54, 241-250. Retrieved from URL: http://nbuv.gov.ua/UJRN/znpgvzdia_2013_54_23.

Попов С. Г. (2009). Социальный менеджмент. Ocb-89, 10-61. Retrieved from URL: https://obuchalka.org/2012112268215/socialnii-menedjment-popov-s-g-2009.html

\section{Contact information:}

Марта Козак

marta.y.kozak@lpnu.ua

Олена Зайченко

olenazaichenko16@gmail.com 